\title{
Seçim Yenilgisi, Parti İçi Muhalefet Ve Hizipleşme Tartışmalarının Gölgesinde Cumhuriyet Halk Partisi XI. Kurultayı (26-30 Temmuz 1954)
}

\author{
DOI: 10.26466/opus.591533
}

\author{
$\underline{\text { Resul Babaoğlu* }}$ \\ *Dr. Öğr. Üyesi, Siirt Üniversitesi, Fen Edebiyat Fakültesi Tarih Bölümü, Siirt/Türkiye \\ E-Posta: babaogluresul@hotmail.com \\ ORCID: 0000-0001-6859-0287
}

Öz

Türkiye'de siyasal kültürün kurumsal temellerinin atılmasında önemli bir yeri olan Cumhuriyet Halk Partisi, bünyesinden birçok siyasal parti ve siyasetçi çıkarmış, aynı zamanda Türkiye'de siyasal hayatın şekillenmesinde önemli bir rol oynamıştır. Birçok bakımdan Türkiye'de ilkleri temsil eden CHP'nin kurumsal tarihinin incelenmesi, ayn zamanda Türkiye'de siyasal hayatın geçirdiği dönüşümü anlamak bakımından da ipuçları taşımaktadır. Şüphe yok ki CHP'deki dönüşümü anlamanın en kestirme yolu parti kurultaylarının çözümlenmesidir. Seçim yenilgilerinden sonra partideki sorunlarm tespit edilmesi noktasında yaşanan suçlamalar ve parti liderliğinde Weberyan anlamda karizmanın aşınması durumu CHP'de parti içi huzursuzluklara yol açmıştır. Araştırmaya konu olan CHP'nin XI. Kurultay'ı, partinin 1954 seçimlerinden sonra yaşadığı meşruiyet krizi ve ilerleyen yıllarda CHP'de hâkim hale gelecek olan hizipleşme olgusunun ilk örneği olması açısından önceki kurultaylardan ayrılmaktadır. Dönemi aydınlatan süreli yayınlar ve anı niteliğindeki eserlere ek olarak parti tarafindan yayınlanmış olan raporlardan yola çıkılarak CHP'de görülen parti içi buhranın çözümlenmesi yoluyla dönemin daha sağlıklı bir şekilde anlaşılmasına katkı sunulması amaçlanmaktadır.

Anahtar Kelimeler: Cumhuriyet Halk Partisi, XI. Kurultay, Parti içi muhalefet, Hizipleşme, İktidar 


\title{
Republican People's Party's XIth Congress in The Shadows of Discussions of Election Defeat, Intra-Party Opposition and The Schism (26-30 July 1954)
}

\begin{abstract}
Republican People's Party, which plays an important role in laying the institutional foundations of the political culture in Turkey, has brought many political parties and politicians from the constitution, also, it has played an important role in shapingpoliticallife in Turkey. The study of the institutional history of the Republican People's party representing the initials in Turkey in many Ways also carries clues in understanding the transformation of political life in Turkey. There is no doubt that the best way to understand the transformation in the RPP is to resolve the party congresses. The accusations of detecting problems in the party after the election defeats and the erosion of charisma in Weberyan sense under the leadership of the party led to internal unrest in the RPP. The XIth Congress of the CHP, which is the subject of the research, differs from the previous congresses in terms of being the first example of the fact that the party experienced the legitimacy crisis after the 1954 elections and the fact that the schism phenomenon would become dominant in the RRP in the following years. In addition to periodicals and memorial works that illuminate the period, it is aimed to contribute to a more healthy understanding of the period through the resolution of the internal party crisis seen in the RRP, based on the reports published by the party..
\end{abstract}

Keywords: Habitus; Cultural Reproduction; Social Reproduction; Studentship 


\section{Giriş}

Türkiye'de siyasal partilerin kökleri XIX. y.y.'da hız verilen Osmanlı anayasal modernleşmesine dayanmaktadır. Ortaylı'nın da ifade ettiği gibi, otokratik monarşiden anayasal bir monarşiye evrilen Osmanlı Devleti, Cumhuriyet Türkiye'sine siyasi parti kadroları, parlamento ve basın gibi siyasal kurumları miras bırakmıştır (Ortaylı, 1983, s.25). Oldukça köklü bir siyasal kültür üzerine tesis edilen ve kurumsallaşmasında bu siyasal kültürün son derece belirleyici olduğu Cumhuriyet döneminin siyasal elitleri, hükmetme sorumluluğu ve devlet idaresinde teşkilatçllık gibi konularda Osmanlı geçmişinin mirasını taşımışlardır. (Rustow, 1969, s.111) Osmanlı Devleti'nin son yüzyılından itibaren iç politikada önemli bir yere sahip olan siyasal partiler, Cumhuriyet döneminde de siyasal hayata yön veren kurumlar arasındadır (Sayarı, 2002, s.10). Bunun yanı sıra, II. Meşrutiyet döneminin en önemli aktörü olan İttihat ve Terakki geleneğinin merkeziyetçi, radikal modernleşmeci ve seküler boyutu Cumhuriyet Türkiye'sinde parti sistemi formasyonunda önemli bir etki bırakmıştır (Özbudun, 1976, s.41).

Türkiye'de 1923-1950 döneminde siyasal yapıya hâkim olan güç ve müessese Cumhuriyet Halk Partisi (CHP) olmuştur. Bu uzun süreçte tek parti olarak iktidarı elinde bulunduran CHP aynı zamanda siyasete yön veren bir mekanizma konumundadır (Akandere, 1998, s.71). Araştırmamıza konu olan bu partinin oldukça çatışmalı siyasal koşulların bir çıktısı olduğu bilinmektedir. Kurtuluş Savaşı'nın kazanılmasının ardından başlayan Lozan Konferansı sürecinin hemen başlarında liderler arasında ortaya çıkan ihtilaflar ve Meclis çatısı altındaki II. Grubun muhalefeti yeni partinin doğuşunu hızlandıran bir etki yaratmıştır. Meclisin yenilenmesi ve Lozan'ın imza sürecinin garantiye alınması sürecinde kuruluşuna karar verilen Halk Fırkası Mustafa Kemal Paşa'ya bağlı kadroyu bir araya getirmiştir (Yllmaz, 2008, s.9). Ankara'da 7 Ağustos 1923'te toplanan milletvekilleri partinin tüzügünü hazırlamaya girişmiş ve yaklaşık bir ay süren çalışmalar 9 Eylül 1923'te son bulmuştur. Aynı toplantıda Halk Fırkası'nın tüzüğü kabul edilerek 11 Eylül'de yapılan 
toplantıda Mustafa Kemal Paşa Halk Fırkası Başkanlığı'na getirilmiştir ${ }^{1}$ (Aysal, Atatürk Döneminde İç Politika, 2012, s.167). Yeni parti kuşkusuz, siyasal, toplumsal ve idari alanlardaki inkılapların yürütülmesi ve halka benimsetilmesi noktasında işlevsel bir mekanizma olarak kullanılacaktı. Nitekim Halk Fırkası bu yönüyle klasik anlamda siyasal partilerin uğraş alanına giren günlük siyasi tartışmaların uzağında olup, Atatürk'ün ifadeleriyle aydınlanma (tenvir) ve rehberlik ( delâlet) konularında roller üstlenmiştir (Dodd, 1991, s.28). Yeni parti halkçılık esası üzerinde vücut bulacaktı, ancak Mutafa Kemal Paşa o zaman kadar kurulmuş olan siyasi partilerin deneyimlerinden faydalanmak gerektiği düşüncesinde olmuştur. Osmanlı Devleti'nin son dönemlerinde görülen parti kavgaları ve çekişmelerinin halk üzerinde yarattı̆̆ Mustafa Kemal Paşa, bu tarz bir siyasal oluşumu hedeflemediği için yeni partinin bütün ulusu temsil etmesi, yani bu partinin sınıflar üstü bir kimlik edinmesini istemiştir (Koçak, Siyasi Tarih (1923-1950), 1995, s.89). Ne var ki 1930'lu yıllara gelindiğinde dünyayı saran otoriter dalganın Türkiye'deki etkileri ve bilhassa 1929 krizinin yarattı̆̆ içe kapanmanın da sonucunda ülke siyasetinde önemli gelişmeler yaşanmıştır. Ülke genelindeki tüm sivil örgütler ve siyasal özerk kuruluşların kapatıldı̆̆ı bu dönemde CHP ile devlet kaynaşması tamamlanmış, parti-devlet hüviyetine bürünen siyasi sistemde bir anlamda CHP, devlet içinde eritilmiştir (Koçak, 2003, s.74; Aysal, 2017).

Parti-devlet özdeşliğinin yeni dönemin ruhuna uygun bir şekilde ortadan kaldırılacağı 1947'de toplanan VII. Kurultay'dan sonra sistemin liberalleşmesi aşamasına geçilmiştir (Kahraman, 2010, s.222). Gerçek şu ki, bir program hareketi ve örgütlenme temeline dayanan İttihat ve Te-

\footnotetext{
1 Partinin kuruluş tarihi ve isimlendirilmesiyle ilgili mevcut karmaşayı önlemek adına şu bilgilere yer vermek gerekmektedir: parti tüzüğünün onaylandığı gün olan 9 Eylül 1923 partinin de kuruluş tarihi olarak kabul edilmesine karşın parti kuruluş dilekçesi 23 Ekim 1923 tarihinde Dâhiliye Vekâletine verilmiştir. Ancak partinin resmi kuruluş tarihi 23 Ekim olmasına rağmen 9 Eylül tarihi üzerinde genel bir kabul vardır. Ayrıca, 11 Kasım 1924 tarihinde Cumhuriyet Halk Fırkası adını alan parti, 10 Kasım 1935 tarihindeki IV. Kurultayda ise Cumhuriyet Halk Partisi şeklinde isimlendirilmiştir. Bkz. Orhan Acun, "CHP'nin Kuruluş Tarihi Üzerine", Tarih ve Toplum, C. 24, No. 141, (Eylül 1995), s132; Mete Kaan Kaynar, Cumhuriyet Dönemi Siyasi Partiler, 1923-2006, Imge Kitabevi, Ankara, 2007, s.41; Hakan Uzun, "Tek Parti Döneminde Yapılan Cumhuriyet Halk Partisi Kongreleri Temelinde Değişmez Genel Başkanlık, Kemalizm ve Milli Şef Kavramları", Çağdaş Türkiye Tarihi Araştırmaları Dergisi, C.9, S.20-21, (Bahar/Güz 2010), s.234; Serhat Hürkan, Halk Firkası'ndan CHP'ye: Soru ve Cevaplarla CHP Tarihçesi (1923-2010), Sinemis Yayınları, Ankara, 2010, s.6.
} 
rakki Fırkası'nın aksine CHP'nin sağlam bir lider kültürüne sahip olması parti içi disiplini sağlayan en önemli etken olmuştur (Hanioğlu, 2014). CHP'de "Değişmez Genel Başkan" ve "Milli Şef" unvanlarıyla pekiştirilen güçlü lider geleneği, tek parti dönemi boyunca parti içinde hizipleşme gibi ayrılıkların yaşanmasının önünde engel olmuştur. Bu dönemde parti içinde yaşanan tartışmalar daha çok yolsuzluk iddiaları, 1924 Anayasasının yapım sürecinde Cumhurbaşkanına meclisi feshetme yetkisinin verilmesi konusunun tartışılması ve kişisel çekişmeler gibi konularda olmuş, ayrıca bu ihtilafları devrim koşullarının basınından yola çıkarak tespit emek de güç olduğu için, döneme ilişkin parti içi muhalefet olgusunu takip etmek de aynı ölçüde güçleşmiştir (Uyar, 2012, s.281-295). Bu durumu CHP kongrelerinden de tespit etmek mümkündür. Tek parti döneminde toplamda yedi defa toplanan kongrelerin bir amacı da partinin halka tanitılması ve sevdirilmesi iken (Uzun, 2010, s.236) 1945'ten sonra başlayan siyasi liberalizasyonun da etkisiyle kongreler partinin yeni döneme uyum sağlaması amacına dönük tartışmalara sahne olmuştur. Bir bakıma, tek parti döneminde düzenlenen kurultaylar tartışma ve çekişmelerden azade iken 1947' de düzenlenen VII. Kurultay'dan itibaren delegeler eleştirilerini daha rahat bir şekilde ifade etmeye başlamışlardır (Çakmak, 2017, s.325). Denilebilir ki, çok partili rekabetçi siyasal düzene geçişten sonra CHP'de yaşanan tartışmalar partinin kurultaylarına birebir yansımış olup 1950 seçimlerinden sonra iki partili sistem şeklinde zuhur eden yapıda CHP'nin yaşadığı meşruiyet krizi ve liderlik tartışmalarının en somut yansımaları Demokrat Parti karşısında alınan seçim yenilgilerinden sonra toplanan kurultaylardaki çekişmeler olmuştur. Nitekim bu araştırmaya konu olan CHP'nin XI. Kurultayı, 1954 seçimlerinde alınan yenilginin partide yarattığı buhranın giderilmesi ve içine girilen umutsuz sürecin tersine çevrilmesi amaciyla parti tüzügünde yapılması planlanan değişikliklerin yol açtı̆̆ı hizipleşme ve tartışmalara sahne olmuştur. Bu yönüyle, dönemin siyasal ikliminin daha iyi anlaşılmasına sağlayacağı katkı ve $\mathrm{CHP}^{\prime}$ de pati içi muhalefet olgusunun niteliği üzerinde yeni tartışmalara kapı aralama potansiyelini taşıması XI. Kurultay'ı ayırıcı kılmaktadır. 


\section{CHP XI. Kurultayı Öncesi Yaşanan Siyasi Gelişmeler}

II. Dünya Savaşının sonunda Türkiye'nin siyasi ve ekonomik çıkarlarının Batıyı işaret etmesinin kesinlik kazanmasıyla birlikte iç siyasette belirgin bir liberalleşme yaşanacağı da sürpriz olmaktan çıkmıştır. Almanya ve İtalya'da güç sahibi olan tek parti idarelerinin II. Dünya Savaşı ile birlikte yıkılması Türkiye'de de siyaseti kaçınılmaz olarak bir yörüngeye oturtmuştur (Karpat, 1959, s.140). II. Dünya Savaşına kadar olan süreçte Türkiye'nin demokrasi serüveni olumsuz tecrübeler içermesine rağmen, Atatürk döneminde iki kez girişilen rekabetçi sistemin de gösterdiği üzere liberal bir siyaset düzeni Cumhuriyet idaresinin demokratik prensiplerle uyumlu bir hale getirilmesi için ulaşılmak istenen nihai hedefti (Babaoğlu, 2017). Nitekim 1944 yılının başlarından itibaren Türk basınında demokrasi kavramı sıklıkla tartışılmaya başladı. Bu süreçte CHP'de yaşanan değişim somut şekilde gözlemlenebilir bir hal almıştır. Parti içinde yaşanan muhalif oluşumlar kısa süre içinde yeni bir partinin doğuşunu hazırlamıştır. Celal Bayar, Adnan Menderes, Refik Koraltan ve Fuat Köprülü'den oluşan muhalefet, Demokrat Parti'nin temellerini atmakla birlikte $\mathrm{CHP}^{\prime}$ nin 27 yıllık tek parti iktidarını sonlandıracak gelişmeleri de beraberinde getirmiştir (Çavdar, Türkiye'nin Demokrasi Tarihi 1839-1950, 1995, s.440). Ancak tahmin edilebileceği gibi bu süreç sancısız bir şekilde cereyan etmemiştir. Hollandalı tarihçi Zürcher'in Huzursuz Bir Demokrasi başlı̆̆ıyla değerlendirdiği bu dönem Meşrutiyet dönemi parti kavgalarını anımsattığı gibi, Türkiye'de siyasi kültürün şekillenmesini sağlayacak birtakım gelişmelere de sahne olmuştur. En önemlisi de 14 Mayıs 1950 tarihinde yapılan seçimlerde muhalefet konumuna yerleşen $\mathrm{CHP}^{\prime}$ nin yeni rolüne uyum sağlamada yaşadığ1 güçlük ve CHP'nin tarihsel geçmişte dayandığı gruplardan farklılaşan bir toplumsal formasyona sahip olarak iktidara yerleşen yeni siyasi aktörlerin benimsenmesi noktasında yaşanan bocalama, iktidar-muhalefet ilişkilerini zehirleyen bir etki yaratmıştır (Zürcher, 2000, s.322).

1950 seçimleriyle iktidara gelişinin ardından DP ile muhalefet arasındaki ilişki git gide uzlaşmaz bir hal almıştır. Millet Partisi'nin dördüncü Kurultayı'nda yapılan konuşmaların Atatürk reformlarına tehdit olarak algılanması üzerine açılan dava bu partinin kapatılmasıyla sonuçlanmıştır. DP hükümetinin muhalefete karşı attığı adımların en şiddetlisi ise 
Adnan Menderes'in Manisa'da yaptığ luk servetiyle bir siyasi partiden ziyade Amerikanvari bir tröstü andırd1ğına yer verdiği konuşmasından sonra bu konunun CHP'nin sahip olduğu mal ve kazançları gündeme getirmesi sonrasında yaşanan gelişmelerdir (Ahmad, 1996, s.71). Cumhuriyet Halk Partisi'nin Haksı İhtisaplar-nın Millete İadesi adı altında çıkan 14.02.1953 tarih ve 6195 sayılı kanun ile CHP'nin genel merkez olarak kullandığı bina ve Ulus gazetesi matbaası dâhil olmak üzere varlıklarına el konulmuştur (Giritlioğlu, 1965, s.304). Muhalefetin maddi açıdan zayıflatıldığı bu koşullarda 1954 seçimlerine gidilmiştir. Muhalefet açısından olumsuzluklarla dolu olan bu süreçte CHP içinde de sular iyice isınmaya başlamıştır. Ulus gazetesinin kapanmasından sonra CHP'nin gereksindiği bir yayın organı çıkarma konusu parti içinde bazı huzursuzluklara yol açmıştır. İnönü'nün de desteğini alarak Yeni Ulus adındaki gazeteyi kişisel girişimiyle çıkaran Nihat Erim'in elde etmiş olduğu güç, partide kişisel ayrılıkların baş göstermesine zemin hazırlamıştır (Arcayürek, 1985, s.141). Toplamda 158 sayı yayınlanan ve son sayısı 22 Mayıs 1954'te çıkan Yeni Ulus, yerini Halkçı gazetesine bırakmıştır. Yeni Ulus gazetesinin partinin resmi yayın organı olduğu iddiasını reddeden Nihat Erim (Yeni Ulus, 14 Şubat 1954) Halkçı gazetesinde de Gündelik Siyasi Sabah Gazetesi ibaresine yer vermiştir (Gülen, 2018, s.344). Ne var ki, Nihat Erim'in Ulus gazetesinin müsadere edilmesinin ardından giriştiği basın faaliyetleri parti içinde huzursuzluklara yol açmış ve XI. Kurultay'da parti bütçesinden yararlanarak yüksek oranda kâr ettiği iddiaları örtük bir şekilde gündeme getirilmiştir.

1950 ve 1954 seçimleri arasındaki dönemde CHP'nin yaşadığı uyum sorunu ve kriz olarak adlandırılabilecek parti içi muhalefet, partinin daha önceki politik koşullarda benzerine rastlanmayan bir savrulma yaşadığını ortaya koymaktadır. 1950 seçimlerinin hemen ardından 29 Haziran 1954'te toplanan VIII. Kurultay'da İnönü'nün teklifiyle parti genel sekreterinin kurultay delegeleri tarafından seçilmesi uygulamasına gidilmesi ve İnönü'nün desteklediği Nihat Erim'e Karşı Kasım Gülek'in partinin genel sekreterliğine seçilmesi CHP'de alışılmadık bir muhalefet odağ1 yaratmıştır (Çavdar, 1994, s.2028). Esasen, bizzat İnönü'nün teklif ettiği bu tüzük değişikliğiyle parti içinde lidere karşı son dönemde dozu artan eleştirilerin yatıştırılması, ama aynı zamanda Erim'in genel sekreterliğe seçtirilerek bu tüzük değişikliğinin boşa çıkarılması amaçlanıyor- 
du (Nart, 1984, s.67). Ancak tahmin edilenden farklı bir sonuç elde dilmesi parti içindeki dengeleri de değiştirmiştir. Genel sekreterlik seçiminde Şemsettin Günaltay, Faik Ahmet Barutçu, Nihat Erim ve Kasım Gülek arasında yaşanan rekabette Barutçu'nun Erim lehine yarıştan çekilmesi ve Günaltay'ın kürsüde yaptığı konuşmada aday olmayı kendisinin arzu etmediği mealindeki talihsiz konuşmasından sonra Gülek oy pusulasını bile kendi elleriyle dağıtmak suretiyle delegelerin sevgisini kazanmayı başarmış ve genel sekreterlik koltuğuna oturmuştur. Böylelikle, parti genel başkanı ile genel sekreterin uyumsuz bir tablo sergilemeleri, genel sekreterin kurultay tarafından seçilmesi yönündeki değişikliğin ne ölçüde isabetsiz olduğunu kanıtlamış ve bu durum CHP'deki huzursuzluğun en önemli nedenini teşkil etmiştir (Barutçu, 1977, s.450).

Toplumsal kökeni ve politik düşünceleri açısından toplumsal yığınlardan farklı olsa da Gülek'in fırsat buldukça yurt gezilerine çıkarak seçmenle kucaklaşması hem kurultaylarda ciddi bir delege desteği elde etmesini sağlamış hem de $\mathrm{CHP}^{\prime}$ de sivilleşme çabalarının başladığı bu yıllarda lider alternatifi olarak öne çıkıştır. Nitekim Kasım Gülek'in genel sekreterliğe seçildiği VIII. Kurultay'dan sonra toplanan kurultaylar, CHP'de merkezi güç odağına sahip olan İnönü ve çevresinin kurultay delegelerinin uhdesine verilmiş olan parti genel sekreterini seçme yetkisinin geri alınması ve milletvekillerinin belirlenmesinde sahip oldukları oransal gücün azaltılması için verdikleri mücadelelere sahne olmuştur.

X. Kurultay, genel merkez ile parti grubu arasındaki sürtüşmenin doruk noktasına ulaştığı bir dönemde toplanmış, bu kurultayda parti içi hiziplerin tam bir hesaplaşmaya gitmesi yönünde beklentiler oluşmuştur (Çavdar, 1994, s.2027). 22 Haziran 1953 tarihinde toplanan X. Kurultay'da Kasım Gülek'in başını çektiği grup ile Halkçı gazetesinin sahibi Nihat Erim ve Cemil Sait Barlas arasındaki rekabet, parti içi muhalefeti ve hizipleşme söylentilerini ayyuka çıkarmıştır. Nihayetinde İnönü ile Gülek arasında yaşanan sert tartışmalara sahne olan bu kurultayda Gülek 860 oydan 709'unu alarak yeniden genel sekreterliğe seçilmiştir (Toker, 1991, s.237). Kurultay'da yapılan oylamada yerini muhafaza eden Gülek, partideki huzursuzluk ve ahenk bozukluğu iddialarına karş1: ... Biz öyle bir topluluğuz ki, içimizde her fert fikrini serbestçe ve acıka ifade eder. $B u$ fikirler her vakit ayn olmaz. Münakaşalar olur ve olmalıdır. Bunlar bir top- 
luluğun hayatiyeti alametidir şeklindeki sözleriyle parti içinde yaşanan ayrılıkların boyutunu normal sınırlar içinde değerlendirmiştir (C.H.P. Genel Sekreteri Kasım Gülek'in C.H.P. Onuncu Kurultay Konuşmaları, 1953, s.12). Gülek'in kurultaydaki konuşmasında dikkat çeken başka bir husus da iktidar partisi çevrelerinin İnönü ile Gülek'in arasının bozuk olduğuna ilişkin yaydıkları söylentileri; hayale kapılmasınlar, boşuna ŭ̆raşmasınlar, Genel Başkanla aramızı ayırmalarına imkân yoktur sözleriyle yalanlamasıydı. Bunun yanında, parti içinden bazı şahısların kendisinin yurt içi gezilerine çok sık çıktığ göreve geldiği zaman yurdun dört bir tarafına gideceği sözünü verdiğini aktararak başladığı konuşmasının devamında sarf ettiği sözleri, muhalefete düşen $\mathrm{CHP}^{\prime}$ de bu yeni döneme en fazla uyum sağlayan politik şahsiyetin yine kendisi olduğunu ortaya koymaktadır:

Cumhuriyet Halk Partisi bu devirde istediği vakit ve istediği yerde vatandaşa hizmete amade, ayă̆ında çarık, elinde asa, köylü ile bağdaş kuran, soğanın kırıp kara ekmeğini yoğurdunu yiyen insana vazife verecektir. Kime vazife verirseniz verin, elbette size hizmet edecek olan insan gerektiği vakit çölleri, karl dağları aşacak, milyonlarca vatandaşın nasırl ellerini sıkacak, alnının terini silecek, gönlünü alacaktır (C.H.P. Genel Sekreteri Kasım Gülek'in C.H.P. Onuncu Kurultay Konuşmaları, 1953, s.24).

1954 yılının Türkiye'de siyaset hayatın etkileyen en öneli olayı kuşkusuz 2 Mayıs'ta yapılan seçimlerdi. Seçimlerden önce toplanan CHP II. Olağanüstü Kurultayı'nda asıl amaç seçimlerden önce partinin içince olduğu durumu masaya yatırmak ve bir seçim stratejisi belirlemekti. Kurultayda söz alan İnönü, konuşmasının büyük bir bölümünü iktidarın muhalefete karşı uygulamalarını eleştirmeye ayırmış, ancak satır aralarında da parti içindeki hesaplaşmanın sinyallerini vermiştir (Genel Başkan İsmet İnönü'nün C.H.P. Kurultayı Olağanstü Toplantısını Açış Nutku, 25 Şubat 1954, s.7). İnönü'nün: Umumi efkârın itimadını üzerine çekmiş olan büyük bir partinin milletvekillerindeki vasıfları Kurultayın teşkilatımıza hakkiyle tanıtmasında fayda vardır şeklindeki sözleri, aslında IX. Kurultay'da kabul edilen ve parti adaylarının tümünün illerdeki yoklama kurullarınca saptanması kuralının değiştirilerek genel merkeze \%20 kontenjan verilmesi amacına dönüktü, (Kili, 1975, s.120) ancak kurultay bu teklifi reddederek elde etmiş olduğu haktan vazgeçmek istememiştir. 
1954 seçimlerinde CHP'nin yüzde 35 civarında aldığı oya rağmen çıkardığ 31 milletvekili karşısında DP, oyların yüzde 58,4'ünü alarak mecliste toplam 503 sandalye sayısına ulaşmıştır. Bu sonuçların $\mathrm{CHP}^{\prime}$ de yarattığı en büyük hayal kırıklığı 1950 seçimlerinde DP'ye oy veren seçmenin kantarın topuzunu kaçırdığ ${ }_{1}$ CHP'ye mesaj verdiği, ancak bu seçimlerde hatasının farkına vararak yeniden $\mathrm{CHP}^{\prime}$ ye yöneleceği yönündeki naif beklentinin boşa çıkmasıyla yaşandı (Uyar, 2017, s.127). Seçim sonuçları belli olduktan sonra CHP ilk iş olarak bir bildiri yayınlayarak etkili bir muhalefet yürütüleceğini açılamış, bir anlamda varlığını koruduğunu kanıtlamanın rahatlığını yansıtma çabalarını ortaya koymuştur (Güngör, 2004, s.266). Bu sonuçların parti üzerinde yıkıcı sonuçlar doğurması kaçınılmazdı. Ancak buna rağmen partide çeşitli isimler tarafından yapılan açıklamalarda iyimser bir tavır gözlenmiştir (Dünya, 11 Haziran 1954). Konuyla ilgili bir açıklama yapan Gülek, seçimdeki başarısızlığı seçim sistemindeki adaletsizliğe hamlederek meclisteki muhalefete etkili bir şekilde devam edileceğini açıklamıştır (Kasım Gülek Konuşuyor... Günümüzün Meşhur Politikacıları, 1956, s.78). Bu arada seçimlerin ardından ortaya atılan iddialara göre İnönü'nün hastalandığ 1 için parti başkanlığından çekileceği konusu kafaları karıştırmaktaydı. Bu konuyla ilgili görüşlerine başvurulan Gülek, İnönü'nün partiden ayrılacağ1 söylentisini yalanlayarak CHP Genel İdare Kurulu'nda ihtilaflar çıktığı iddiasını da reddetmiştir (Yeni Sabah, 5 Mayıs 1954). Aslında bu iddia daha sonraki günlerde Ahmet Emin Yalman'ın bir köşe yazısında yer verdiği bilgilerden sonra yeniden alevlenecektir. İnönü ile 1950 seçimlerinden önce yapmış olduğu bir görüşmede seçimi CHP'nin kazanması üzerine İnönü'nün partiden istifa edip yerini daha genç bir partili arkadaşına bırakacağını söyleyerek seçimlerin kaybedilmesi durumunda da ideal bir muhalefet lideri örneğini koyacağını ifade ettiğini iddia eden Yalman gelinen bu noktada da İnönü'nün siyasi rolünün kalmadığını savunmuştur (Yalman, C.H.P.'de Liderlik, 1954). Aslında 1950-1954 yılları arasında yapılan kurultaylar bir anlamda CHP'deki dönüşümün sağlanmaya çalışıldığ nezdinde ne derece kabul edildiğini 1954 seçimlerinde alınan sonuçlar ortaya koymaktadır (Unat, 2016, s.328). 


\section{CHP'de Islahat Tartışmaları ve Kurultay Öncesi Bölünme}

2 Mayıs 1954 tarihinde yapılan seçimler DP'nin ezici üstünlüğüyle sonuçlanınca 1950 seçimlerinden sonra yapılan yanlışların düzeltileceği beklenen $\mathrm{CHP}^{\prime}$ de bu yönde bir değişim yaşanmaması üzerine parti içinde belirgin bir bölünme yaşanmıştır. Bu süreçte, partide ıslahat yapılması, kadro ve politika değişikliğine gidilmesi istenmeye başlamış, İnönü, sabır ve sükûnet önerirken Gülek ise mücadelenin sine-i millette sürdürüleceğini belirtmiştir. Bu gelişmeler sırasında yapılan parti meclis toplantısında Erim-Gülek çatışması yaşanmıştır. Halkçı adlı gazeteyi çıkaran Erim mücadelesini bu yayın organında sürdürürken bu durumun partiye zarar verdiği düşünülmüştür (Balcı M. , 2015, s.172). Seçimlerden sonra toplanan CHP Meclis Grubunda partide islahat yapılması teklifleri gündeme alınmıştır. Meclis Grup Başkan Vekillerinden Faik Ahmet Barutçu, partide ıslahat yapılmasının şart olduğunu ve bu hususta bir teklif hazırladığını belirterek tüzük ve program üzerinde esaslı ıslahat isteyen teklifini Meclis Başkanlığı'na vermiştir. Bu gelişme üzerine parti meclisinde bir sslahat komisyonu oluşturularak Temmuz ayında toplanacak olan kurultaya bazı tekliflerin sunulacağı ifade edilmiştir (Dünya, 13 Haziran 1954). Toplantıda Gülek ile Erim arasındaki ayrışma iyice açı̆̆a çıkmıştır. Genel sekreterin kurultay değil, parti meclisi tarafından seçilmesi ve Ulus gazetesinin yeniden çıkarılmasına oy birliğiyle karar verilmiş ve bununla ilgili tüzük değişikliği genel idare kurulu tarafından yapılıp Temmuz'da toplanacak olan kurultaya sunulacaktı (Nart, 1984, s.127). Ayrıca partide genel başkanlığın ilga edilerek Bunun yerine günlük politikadan uzak, partinin sevk ve idaresinden sorumlu ve sadece partinin umumi politikasında söz söyleyebilecek salahiyette bir liderin kurultay tarafından seçilmesi, buna mukabil genel sekreter ve genel idare kurulunun parti meclisi tarafından seçilmesi kararlaştırılmış (Yeni Sabah, 13 Haziran 1954; Dünya, 13 Haziran 1954), ancak bu tekliflerin kurultay tarafından ne şekilde karşılanacağ da bir soru işareti olarak belirmiştir (Akşam, 22 Temmuz 1954). CHP içindeki tartışmaların mahiyetini iktidara yakın olan Zafer gazetesinde daha açık bir şekilde görmek mümkündür. Parti içinde huzursuzluklara sebep olan bazı iddiaların bizzat bu iddialara hedef olan isimler tarafından yalanlanmasına rağmen ortaya çıan huzursuzluğun boyutu, üzerinde durulmayı hak edecek 
ölçüdedir. Ulus gazetesinin kapatılmasından sonra Erim tarafından önce Yeni Ulus ardından da Halkçı adlı gazetelerin çıkarılması ve Erim'in partinin adını kullanarak 150-300 bin lira civarında para kazandığı söylentileri iktidar basınında gündemde tutulmaya çalışılmıştır. Bu noktada partinin uğradığı zararın ne şekilde çıkarılacağı sorununun kurultayda şiddetli tartışmalara yol açacağı beklentisi aktarılmıştır (Çevik, C.H.P.'yi Islah Edecek Komisyon Faaliyeti, 1954). İktidara yakın basında yer verilen bir diğer iddia da parti içinde bazı isimlerin CHP'nin tarihi vazifesini ifa ettiğini, bunun için artık tarihe mal olması gerektiğini ileri sürerek kurultayda bu iddialarını sesli bir şekilde dile getirecekleri yönündeydi (Çevik, C.H.P.'nin Atisi ve Yeni Kararlar, 1954). Aslına bakılırsa bu görüş, Islahat Komisyonunun toplantısında Cemil Sait Barlas tarafından da dile getirilmiştir. CHP'nin geçmişte yapıp ettikleriyle övünmek yerine bu şartlar içinde kendi kendini feshetmesi gerektiğini dile getiren Barlas, partide yeni bir tartışmaya kapı aralamıştır (Yeni Sabah, 4 Temmuz 1954). Öte yandan partinin feshedilip başka bir isimle yeni bir partinin kurulması istekleri karşısında İnönü ve Gülek ortak bir tutum takınarak partinin yaşatılması için çalışmaya hazır olduklarını dile getirince bu yöndeki istekler rafa kaldırılmıştır (Güngör, 2004, s.270).

Zafer gazetesinin $\mathrm{CHP}^{\prime}$ deki gelişmeleri pejoratif tarzda ele aldığı görülmektedir. Öyle görünüyor ki CHP'deki hizipleşmeyi iktidar çevreleri de yakından takip etmişlerdir. Kasım Gülek'in partide tesanüt olduğuna ilişkin yapmış olduğu açıklamayı konu alan bir köşe yazısında: Evet Genel Sekreterin beyan etiği gibi Halk Partisi'nin içinde tesanüd varmış! Bu tesanüd olduğu içindir ki Islahat Komisyonu, parti teşkilatındaki genel sekreterlik kadrosunu lağvetmeyi düşünmüş ve o mübarek zatı kurultayda açıkta bırakmak için tedbirlerini almıştır sözleriyle Gülek'in CHP'deki gelişmeleri gizlemeye matuf açıklamalarını eleştirmiştir (Fenik M. F., Şu C.H.P.'deki Tesanüt Hikayesi, 1954). Başka bir yazısında CHP'de islahat fikrinin ortaya atılmasının bizatihi bozukluğun kabul edildiği anlamına geldiğini savunan Mümtaz Faik Fenik, CHP'de asıl sorunun program ve tüzük değiştirilmesi olmadığını, partiyi yöneten zihniyetin asıl değiştirilmesi gereken bozukluk olduğunu iddia etmiştir (Fenik M. F., Islahat İstemek Bozukluğu Kabul Etmektir, 1954). Öte yandan Islahat Komisyonunun çok cesur adımlar atmak yerine ayrıntılara boğulduğunu içeren bir haberde CHP'de tartışmaların şahıslar etrafında dönmesi eleştirilerek ismi 
kötü uygulamalarla anılan bazı isimlerin tasfiye edilmeleri gerektiği savunulmuştur (Yeni Sabah, 17 Temmuz 1954). Bununla birlikte iktidara yakın olan basın organlarında $\mathrm{CHP}^{\prime}$ ye yönelik ortaya atılan iddiaları hedef alan bir yazıda: iktidarın emellerini açı veya gizli müdafaa etmeyi itiyad edinmiş beslemeler de çalakalem Halk Partisi içinde nifak ve ikilik yaratmakla ve bu partiyi temelinden sarsıp parçalamağa çalışmakla meşguldürler cümleleriyle CHP idarecileri uyarılmıştır (CHP Uyanık Olmalı, 1954).

Parti meclisinin toplandığı sıralarda İnönü'nün partiden istifa edeceği haberleri yeniden yayılmıştır. Bu iddialar üzerine açıklama yapan Gülek; İnönü'nün partiden istifa edeceği ve parti idarecileri arasında ihtilaf olduğu haberlerinin gerçeği yansıtmadığını belirtmiştir (Yeni Sabah, 16 Haziran 1954). Hemen ardından söz alan Nihat Erim de Gülek'i doğrulayarak Ulus ve Yeni Ulus gazeteleriyle ilgili çıkarılan söylentileri yalanlayarak kendisinin Yeni Ulus'u partiye bir fedakârlık olsun diye çıkard1ğını açıklamıştır. Her ne kadar, Gülek ve Erim açıklamalarıyla parti içindeki anlaşmazlıkları yalanlamış olsalar da partideki diğer bazı isimler aynı görüşte değillerdi. Eski Trabzon Milletvekili Cahit Zamangil, yaptığı konuşmada: "Sizi şerefimle temin ederim ki, böyle bir ihtilaf mevcuttur. Ihtilaf vardır ve bu parti kademelerine sirayet etmiştir" demiştir (Dünya, 13 Haziran 1954). İzmir İl Başkanı Şevket Adalan da Ulus gazetesi adının Nihat Erim tarafından istismar edildiğini ve Erim'in Ulus gazetesi çıarılması teşebbüsünü baltaladığını beyan etmiştir (Dünya, 13 Haziran 1954).

CHP'de kurultay günü yaklaştıkça bazı fikirlerin basın organlarında daha net bir şekilde tartışılmaya başladığı görülmüştür. Aslına bakılırsa, kurultay delegelerinin önemli bir kısmının desteğine sahip olduğu düşünülen Gülek'e karşı birtakım iddiaların üst perdeden dile getirilmesiyle, kurultaya katılacak olan il delegelerinin kafalarında soru işaretleri uyandırmak da amaçlanmış olabilirdi. Zira Erim cephesine yakınlığıyla bilinen Cemil Sait Barlas, Son Havadis adlı gazetede bu yönde bir alg1 yaratacak şu sözlere yer vermiştir:

Tek parti devrinden kalma bir gelenek vardır. Cumhuriyet Halk Partisi hakkında belli bir iki kişiden başka kimsenin görüşünü, düşünüşünü açıklamaya hakkı yoktur... Önümüzdeki günlerde toplanacak olan kurultay arifesinde görüşümüzü, düşünümüzü açıklamayı faydalı bulmakta, hatta Cumhuriyet Halk Partisi'ne karşı bir vazife saymaktayız. Çünkü toplanacak olan kurultaydan 
evvel gelecek delegelerin parti kaderine dair belli fikirleri bilmeleri lüzumludur (Barlas, C.H.P.'nin Durumu, 1954).

C.H.P.'nin Durumu başlığıyla bir yazı dizisi kaleme alan Barlas, CHP'deki sıkıntıların tek parti anlayışından kaynaklandığını savunarak 1950 seçimlerinden sonra kabul edilen parti tüzügüne göre oluşturulan Genel Başkan, Genel Sekreter ve İdare Heyeti'nin partide üç başlı bir yapı oluşturduğunu ifade etmiştir (Barlas, C.H.P.'nin Durumu II, 1954). Dizinin 5. yazısında genel sekreterliğe yer veren Barlas, 1950'ye kadar parti divanınca seçilen genel sekreterin 1950 Kurultayı'nda İnönü tarafından komisyona yapılan teklif üzerine kurultay tarafından seçilmesinin kabul edildiğini hatırlattıktan sonra, CHP'nin çok başlılıktan kurtulması gerektiğini bunun da yapılacak olan kurultayda sağlanabileceğini ileri sürmüştür (Barlas, C.H.P.'nin Durumu V, s.16).

$\mathrm{Ne}$ var ki, ilerleyen günlerde $\mathrm{CHP}^{\prime}$ nin içinde bulunduğu durumun basın tarafından yakından takip edildiği görülecektir. CHP'de yaşanan gelişmeleri değerlendiren Falih Rıfkı Atay, seçimlerde alınan yenilginin önemli değişimlere gebe olduğunu belirterek seçimler arasında ehemmiyet verilmeyen tenkit ve şikâyetlerin dikkate alınması ve bunları giderici değişiklikler yapılması lazım gelir. Bu tenkit ve şikâyetler merkezdeki bazı şahsiyet ve hiziplerin muhalefet taktiği ile yine merkezdeki şahsi mülahazalarn umumi parti menfaatleri üstünde tutulması üzerinde toplanmaktaydı sözleriyle bu noktaya nasıl gelindiğini açılamıştır (Atay, 1954). Atay, makalesinin devamında bu aşamadan itibaren kurultayların CHP'de nasıl bir işlev kazandığını şu cümlelerle ifade etmiştir: Bir iktidarın başlıca ikbal ve nimet makamlarının merkezde bulunanlar arasında bölüşüleceği, mutlaka merkez nüfuzlarm elde ederek daha önceden kurultayları adaylık işlerini bu nüfuzların kontrolü altına almak kestirme yol olduğu zihniyeti hemen bir yana atılmalıdır (Atay, 1954). CHP'deki gelişmeleri köşesine taşıyan Ahmet Emin Yalman ise, parti saflarındaki ki cephenin bundan böyle ayn kazanda kaynamasının mümkün olmadığının altını çizerek gözü dönmüş ihtirasçıların sözcüsü olarak nitelendirdiği Gülek'in ortaya firlayarak yaptı̆̆ı açıklamalarda daha önce de yaptığı gibi İnönü'ye karşı kurultayı arkasına alarak genel sekreterlik koltuğunu koruyacağın umuyor ve bu takdirde arkasından gitmek istemeyenlere kapıyı gösteriyor cümleleriyle Gülek'i eleştirmiştir (Yalman, C.H.P.'de İki Cephe, 1954). 26 Temmuz'da toplanacak olan kurultay öncesinde basının ağırlıklı olarak üzerinde durduğu siyasi konu $\mathrm{CHP}^{\prime}$ de 
yaşanan hizipleşme olmuştur. Yazılarına bu minvalde devam eden Yalman, Gülek'i başka bir yönden eleştirerek yıkıcı bir muhalefet yaptığını savunmuştur. Vatansever hislerle hareket eden bir murakabe partisinden beklenecek yol nedir? Hayranlık ifade eden yanlarm hazzın duymak... Türkiye'nin elde ettiği harici itibarla iftihar etmek... Halk Partisi'nin Kasım Gülek tarafindan temsil edilen kolu, bu normal ve tabii yola tamamiyla zit bir istikamet tutuyor. Bu kol, memlekette yapılan her iyi işe gözünü yumuyor. Her şeyi kapkara görüyor ve öylece göstermeğe çalışıyor. Hem de yalnız kendi vatandaşlarına değil... Kasım Gülek ve arkadaşları her tarafa ă̆lar kurmuşlardır. Memlekete gelen belli başl her ecnebiyi burada yaşayıp harice haber aksettirenleri ağlarına düşürüyorlar (Yalman, Bozguncu Politika, 1954). Görüldüğü gibi, CHP içindeki bölünmeler basın organları tarafından da takip edilmiş, hatta bölünmenin tarafları basın nezdinde de mevzi kazanma mücadelesi vermişlerdir.

Hüseyin Cahit Yalçın, CHP içindeki huzursuzlukların partide esaslı ıslahatlar yapılmasıyla çözüleceğini düşünen iktidar çevrelerini hedef aldığı Halkçı gazetesindeki yazısında Halk Partisi'nin ıslahı demek de onların zihninde ve nihayet açıktan açığa ă̆ızlarındaki İsmet İnönü'nün Halk Partisi Genel Başkanliğından çekilmesi demektir. O kadar hücum ettikleri Nihat Erim'e bile hemen hemen göz yumacakları hissolunur. İle İsmet İnönü partiden çekilsin. İsmet İnönü'nün şahsma tevdi edilen hücumları biz Halk Partisi kalesinde bir gedik açmak için takip edilen bir taktik telakki ediyoruz sözleriyle İnönü'nün CHP içindeki karizmatik konumunu hatırlatmıştır (Yalçın, 1954).

\section{İnönü'nün Açış Nutku ve XI. Kurultay'a Sunulan Rapor}

26 Temmuz'da toplanan kurultay öncesinde basını en fazla meşgul eden konu parti içindeki ayrışmaydı. CHP'nin Sinesinde Çarpışan İki Zihniyet başlığıyla verilen bir gazete haberinde Faik Ahmet Barutçu başkanlığındaki ıslahatçı grup ile statükonun devamından yana olan grup arasındaki çekişmenin kurultaya damga vuracağı vurgulanmıştır (Akşam 26 Temmuz 1954). Islahat komisyonunun hazırladığ1 raporun yer aldığı haberlerde kurultaydaki tartışmaların da bu rapor etrafında gelişeceği beklentisi yer almıştır (Cumhuriyet, 24 Temmuz 1954). Tüzük tadilatı yüzünden iki hizip arasında şiddetli bir mücadele yaşanacağı beklentile- 
ri basında yer almıştır (Cumhuriyet, 26 Temmuz 1954; Yeni Sabah, 26 Temmuz 1954). Öte yandan, ilk görünüşte bir tüzük tadili gibi sırf uygulamadaki aksaklıkların bertaraf edilmesi şeklinde tezahür eden islahat girişiminin gerçekteyse Genel Sekreter Kasım Gülek'in şahsını hedef tuttuğu artık açıktan açığa dillendirilmeye başlamıştı (C.H.P.'de Kulis Arkası Faaliyetler Arttı, 1954). Bu arada kurultay için Ankara'ya gelen il delegelerinin büyük bir kalabalık oluşturduğunu aktaran Doğan Nadi, Ankara' da lokanta ve otellerde muazzam bir yoğunluk yaşandığını ifade ederek illerden gelen delegelerin aralarında hararetli tartışmaların yaşandığını belirtmiştir (Nadi, 1954). Ankara'nın sokak ve caddelerinde en çok konuşulan konunun CHP kurultayı olduğuna yer verilen bir haberde illerden gelen delegelerin yoğun bir kulis faaliyeti içinde oldukları vurgulanmıştır (Zafer, 26 Temmuz 1954).

26 Temmuz Pazartesi günü İnönü'nün riyasetinde toplanan kurultaya DP adına Nusret Kirişçioğlu ile Avni Yurdabayrak, CMP adına da Osman Bölükbaşı ile Abdurrahman Boyacıgiller katılmışlardır. Kurultaya 600'ü bulan delege katılmış, oturuma yoklama yapılarak başlanmış, İstiklal Marşı ve saygı duruşunun ardından kurultay başkanlığı için seçim yapılmıştır. Başkanlık seçiminde itiraz sesleri yükselirken İnönü'nün desteklediği Barutçu başkanlığa seçilmiştir (Akşam, 27 Temmuz 1954).

Konuşmasının ilk bölümünü 1954 seçimlerine ayıran İnönü, seçimler öncesinde seçmenlere yönelik bir seçim beyannamesi yayınlayan partinin sadece kendileri olduğuna yer vererek seçim mücadelesi kapsamındaki faaliyetlerin $\mathrm{CHP}^{\prime}$ nin kudretli ve faydalı bir parti olduğunu kanitladığını savunmuştur (C.H.P. XI. Kurultayı Genel Başkan İsmet İnönü'nün Açış Nutku, 1954, s.3). Seçimlerin müsavi şartlarda yapılmadığına konuşmasında yer veren İnönü, radyo meselesine değinmiş ve seçim sonuçlarının ayrıntılı bir analizini yaparak CHP'nin aldığı \%35 civarındaki oyun yabana atılmaması gerektiğini savunmuştur (C.H.P. XI. Kurultayı Genel Başkan İsmet İnönü'nün Açış Nutku, 1954, s.5). Seçimlerden sonra iktidar partisinin bazı kanun değişikliklerine giderek muhalefeti boğmaya çalıştığını iddia eden İnönü, memurlar ile ilgili çıkarılan tasfiye kanununun da muhalefeti yaşatmak istemeyen bir iktidar anlayışının ürünü olduğuna yer vermiştir. Islahat Komisyonunun çalışmalarına da değinen İnönü, komisyonun değerli mütalaalarını esaslı istikametler ve tatbikat üzerinde bildiren komisyonun partinin idari ve umumi 
teşkilatı üzerine de telkinlerde bulunduğuna yer verdikten sonra, CHP'nin büyük bir sorumluluk yüklendiğini vurgulayarak konuşmasını sonlandırmış ve XI. Kurultay'ın siyasi tarihe geçecek mahiyette çalışacağına olan inancını vurgulamıştır (C.H.P. XI. Kurultayı Genel Başkan İsmet İnönü'nün Açış Nutku, 1954, s.15). Daha ziyade, demokrasilerde iktidar ve muhalefet partileri arasında işbirliğine dayalı bir ilişkinin var olması gerektiği üzerine bina edilen İnönü'nün konuşması, seçimlerin demokratik usullerle yapılması, Kırşehir'in ilçe yapılması, memurlara yönelik tasfiye kanunu ve hâkimlerin erken emekli edilmeleri gibi CHP'nin iç sorunlarından uzak konuları içermesi basının da dikkatinden kaçmamıştır (Cumhuriyet, 27 Temmuz 1954).

Kurultay'ın ilk gününde Genel İdare Kurulu tarafından sunulan raporda öncelikle CHP'nin muhalefet konumuna düştüğü 1950 seçimlerinden sonraki süreç ele alınmıştır. 1951 ara seçimlerinden birkaç ay sonra Halkevlerinin kapatılarak CHP'nin zayıflatılmaya çalışıldığı, 1953'te partinin mallarına ve Ulus gazetesi matbaasına el konulması gibi saldırılara ek olarak 1954 seçimlerinden önce radyonun iktidar partisine hizmet eder bir şekle sokulduğu ayrıntılı bir şekilde anlatılmıştır (C.H.P. Genel İdare Kurulu'nun 11. Kurultaya Sunduğu Rapor 26-7-1954, 1954, s.5-7). Bununla birlikte CHP'nin teşekkülünden sonra çağdaş bir demokrasi hüviyeti kazanan Cumhuriyet rejiminin partiler sistemi ile yönetilmeye başlandığı tarihten itibaren Türk demokrasisine hizmet eden CHP'nin getirdiği seçim kanunlarıyla sistemi yumuşatmasına karşın DP iktidarından sonra çeşitli yollarla muhalefetin ortadan kaldırılmasına çalışıldığ1 iddia edilerek çoğunluk esasına dayanan seçim sisteminin mutlak surette nispi temsile dönüştürülmesi gerektiği ileri sürülmüştür (C.H.P. Genel İdare Kurulu'nun 11. Kurultaya Sunduğu Rapor 26-7-1954, 1954, s.13). Bundan sonra, kurulan hususi komisyonun tekliflerine yer verilen raporda ikinci bir meclis kurulması, çoğunluk sistemi yerine nispi temsilin benimsenmesi, hukuk devletinin tesis edilebilmesi için hâkim teminatının sağlanması, adli personelin emeklilik ve atanma işlerinin siyasi ve idari mercilerden alınarak Yüksek Hâkimler Şurası'na verilmesi, seçim güvenliği, memurlara sendika kurma hakkının verilmesi ve basın hürriyetinin sağlanması gibi konular maddeler halinde sıralanmıştır (C.H.P. Genel İdare Kurulu'nun 11. Kurultaya Sunduğu Rapor 26-7-1954, 1954, s.16). Görüldüğü gibi, bu teklifler arasında yer alan hukuk devleti fikri 
ve Yüksek Hâkimler Şurası gibi teklifler ilk defa dile getirilerek siyasetteki tıkanmaya çözüm aranmıştır.

\section{Kurultayda Gündeme Gelen Konular ve Alınan Kararlar}

İnönü'nün Kurultay'ın açılışında yaptığı konuşma basın tarafından ilgiyle takip edilmiş ve ertesi gün çıkan gazetelerde konuşmanın içeriğine dair haberler servis edilmiştir. İnönü'nün Partimizin takip edeceği politika, siyasi emniyet şartların gerçekleştirmek olacak sözleri büyük puntolarla okuyucuya aktarılmış ve çoğunluk esasına dayanan seçim kanunun değiştirilmesi gerektiğine ilişkin sözlerinin altı çizilmiştir. Açılış konuşmasinda yer alan; ... her kim olursa olsun, bazı şahıslarm mahut zevat tabiriyle, yahut şu veya bu sözle aramıza sokacakları bütün fenahklara dikkatinizi celbederim şeklindeki sözler kurultay öncesinde dolaşıma sokulan bazı söylentilerin üzerini örtmeye yönelik olduğu kolaylıkla tahmin edilebilir (Dünya, 27 Temmuz 1954). Öte yandan, İnönü'nün seçim yenilgisini açıklamaya dönük ifadelerine yer verilen bir gazete yazısında da seçim sistemi ve radyonun kullanımı gibi bahanelerin seçim yenilgisini açıklamaya yetmediği vurgulanmıştır (Kurultayın İlk Günü, 1954). İnönü'nün konuşmasında asıl üzerinde durulması gereken husus, seçim sisteminin ve iktidarın anti-demokratik tutumunun muhalefeti boğduğu ve bu şartlarda muhalefetin yaşamasına imkân kalmadığı mealindeki sözleriydi. Ne var ki bu yöndeki kanaatler kurultayda başka isimler tarafından da benimsenecek ve CHP'nin meclisten çekilmesi bile gündeme gelecektir. İnönü'ye ait olan şu cümle: Hükümet, muhalefeti artık siyasi hayatımızda mevkii olan bir müessese olarak tanımıyor kurultayın ikinci gününde meclisten çekilme konusunun gündeme gelmesine zemin hazırlayacaktır (Dünya, 27 Temmuz 1954).

$\mathrm{Bu}$ arada umumi heyet toplantılarında da bu konu gündeme gelmiş, sert tartışmalara sahne olan kurultayda Adana delegesi Ahmet Küspeci, eskiden Demokrat ve Adnan Menderes'in mesai arkadaşı olduğunu söyleyerek lafa başlamış ve Menderes'e ağır hücumlarda bulunmuştur (Akşam, 28 Temmuz 1954). İktidar cenahının da yakından takip ettiği kurultaydaki bu hadise büyük tepki uyandırmıştır. Hakaretamiz ve iğrenç tecavüzlerinden dolayı bir delege hakkında Başvekilimizin de müsaadesiyle adli takibat açıldı başlığıyla verilen haberde Ankara Cumhuriyet Müddeiu- 
mumiliği 'nin harekete geçtiği bilgisi yer almıştır (Zafer, 28 Temmuz 1954; Cumhuriyet, 28 Temmuz 1954). Öte yandan kurultayın ilk gününde kâtip olarak seçilen Sabahat Erdemir'in devlet reisine hakaretten dolayı yargılandığı davadan 6 ay ceza almış olması hatırlatılarak bu şahsın kâtipliğe seçilmesi eleştiriye konu edilmiştir (Zafer, 29 Temmuz 1954). Aslında bakılırsa iktidar basını ilk günden itibaren kurultaya karşı olumsuz içerikte haberler yayınlamıştır. Kurultay'ın henüz ertesi günü Türk Deoletine Karşı Cephe Alan Kurultay başlıklı bir yazı kaleme alan Mümtaz Faik Fenik CHP'nin demokratik esaslar dâhilinde bir parti hüviyetinde olup olmadığına henüz karar veremediğini vurgulayarak divan kâtipliğine seçilen Sabahat Erdemir'den dolayı partiyi şiddetle eleştirmiştir (Fenik M. F., Türk Devletine Karşı Cephe Alan Kurultay , 1954).

Kurultay'ın ikinci gününde toplanan Ana Davalar Komisyonu'ndaki görüşmelerde seçim kanunu değişmeden partinin seçimlere katılmama ve meclisten çekilme hususu tartışılmıştır. Komisyon başkanı Salih Tüzel'in rejim teminat altına alınmadıkça seçimlere girmeme yönündeki konuşması birçok delege tarafından benimsenmiştir (Halkçı, 30 Temmuz 1954). Esasen bu konu kurultay toplanmadan önce de delegelerin en çok üzerinde durdukları meselelerden biriydi. Basına göre delegelerin çoğu, bugünkü şartlar içinde muhalefetin ve CHP'nin meclisi terk etmesinin yerinde bir hareket olacağı kanaatini taşıyorlardı (Yeni Sabah, 27 Temmuz 1954). Bu konuda İnönü'nün aldığı tavır delegelerin çoğunluğuna göre daha 1lımlıydı. İnönü, gayrı meşru yollarla mücadelenin doğru olmadığını, elde mevcut kanunlar ne ise onlar dâhilinde mücadelenin zaruri olduğunu söylemiş, hatta memlekette nizam harici bir hava yaratacak olan bu gibi kararlara varılırsa kendisinin aralarında bulunmayacağını ilave etmiştir (Akşam, 28 Temmuz 1954; Yeni Sabah, 29 Temmuz 1954). Erim'e göre, İnönü'nün partiden ayrılma kozunu öne sürmesi, delegelerin meclisten çekilme isteklerini yeniden gözden geçirmelerini sağlamıştır (Erim, 2005, s. 557).

Yapılan hararetli tartışmalar sonucunda hükümete nispi temsil usulünün kabulü, hâkimlerin teminatı, üniversite muhtariyeti, yüksek hâkimler şurasının ihdas edilmesi gibi teklifler götürülmesi ve bu tekliflerin kabul edilmemesi durumunda meclisten çekilme kararının CHP Meclis Grubu ile Genel İdare Kurulu'na birakılması konusunda karara varılmıştır (Akşam, 28 Temmuz 1954). Bazı delegelerin partinin meclis- 
ten çekilmesi ve mevcut şartlar altında seçimlere katılmaması yönündeki isteklerine kararlı bir şekilde itiraz eden İnönü'nün ılımlı tavrı iktidara yakın basında eleştiri konusu yapılmıştır. Böyle bir kararın alınması durumunda partiden istifa etme kartını öne süren İnönü'nün bu tavrını eleştiren bir gazete haberinde CHP'nin hala bir şef partisi olmaktan kurtulamadığ 1 yorumuna yer verilmiştir (Zafer, 30 Temmuz 1954).

Kurultayda gündeme gelen diğer bir husus da genel sekreterliğin lağvedilmesi, dolayısıyla Kasım Gülek'in ekarte edilmesiydi. Bilindiği gibi, Gülek karşıtı cepheyi oluşturan ve Erim'in başını çektiği grup bu teklifi komisyona getirerek bir sonuç almak niyetindeydi. Ancak genel sekreterliğin lağvedilmesini reddeden komisyona yeni oluşturulacak olan 30 kişilik parti meclisinin bu yetkiye sahip olması teklifi bile kabul ettirilemeyince Gülek, muhaliflerine karşı iki defa galip gelmeyi başarmıştır (Yeni Sabah, 30 Temmuz 1954). Genel idare kurulunun lağvedilmesinden sonra tesis edilen parti meclisi için yapılan seçimlere gösterilen 68 aday arasından 30 kişi seçilmiştir. Bunun ardından yapılan oylamada 472 oyun 456'sını alan İnönü genel başkanlığa ve Kasım Gülek de 169 oy alan Ferit Melen'e karşı 295 oyla yeniden genel sekreterliğe seçilmiştir (Akşam, 31 Temmuz 1954). Bu arada, komisyonda konuşulan gazete meselesi için söz alan Erim, 150 bin lira kar ettiği iddialarını yalanlayarak henüz yılsonu olmadığı için böyle bir karın söz konusu olmadığını söylemiş, dahası kar ya da zararıyla gazeteyi partiye devretmeye hazır olduğu şeklinde akıllıca bir teklif yapmıştır (Erim, 2005, s.555). Bunun üzerine söz alan Gülek, zarar olacaksa bunun partiye hamledilmesinin kabul edilemeyeceğini dile getirmiştir (Erim, 2005, s.556). Daha sonra komisyonun hazırladığı rapor da Erim'i doğrulayınca Ulus gazetesinin yeniden çıkarılması için bir matbaacılık ve bir gazetecilik şirketinin kurulması kararlaştırılmış, böylelikle Erim'i töhmet altında bırakan suçlama ve söylentilerin sonlanması sağlanmıştır (Vatan, 2 Ağustos 1954).

Kurultaya teklif edilen tüzük değişikliğinin reddedilmesi Gülek'in muhaliflerine karşı elindeki gücü koruduğu anlamına geldiği gibi, iktidara yakın olan basın tarafından bu sonuç CHP'nin sslahat kabul etmediği şeklinde yorumlanmıştır (Fenik, 1954). Buna benzer bir yorum da Yeni Sabah gazetesinde yer alan bir değerlendirmede göze çarpmaktadır. Yapılan yoruma göre $\mathrm{CHP}^{\prime}$ de eski huyların devam ettiği ve herkesin memnun edilmek istenmesinin böyle bir sonuca yol açtığ 
sürülmüştür (Yeni Sabah, 31 Temmuz 1954). Kurultayın ardından Zafer gazetesinde yer alan bir değerlendirme yazısında sert ifadeler dikkat çekmektedir. Kurultayın hiçbir değişiklik yapılmadan sona erdiğine yer verilen yazıda; Hani parti A'dan Z'ye kadar ıslahata muhtaçtı? Hani seçimleri niye kaybettiğini araştırıp bulacaktı? Hani parti meclisi bir komisyon seçmişti ve bir ıslahat raporu hazırlamıştı? Sorularına yer verilerek kurultay hedef alınmıştır (Orhon, 1954).

30 Temmuz'da kurultayın sona ermesinin ardından CHP tarafından bir tebliğ neşredilmiştir. Tebliğgde; CHP'nin meşru yollardan yürüyerek ve meşru vasıtalar kullanarak takatinin son haddine kadar mücadeleye devam azminde olduğu belirtilmiştir (Yeni Sabah, 31 Temmuz 1954). Tebliğde yer alan konular kısaca incelendiğinde iktidara yönelik bazı itham ve taleplerin sıralandığı görülmektedir. Demokrasi ve hukuk devleti nizamının prensipleri ve müesseseleri ile hala erişilmesi gerekli uzak bir hedef halinde bulunduğuna yer verilen tebliğde bazı kavramların siyasal literatüre kazandırıldığı gözlenebilmektedir. Bunun dışında seçim güvenliği, nispi temsil esası, basın ve radyonun muhalefet tarafından serbestçe kullanılabilmesi, İnsan Hakları Evrensel Beyannamesi ve Avrupa İnsan Hakları Beyannamesi metin ve ruhuna uygun siyasi faaliyetin emniyeti gibi hususlar tebliğde üzerinde durulan konular arasındaydı (Yeni Sabah, 31 Temmuz 1954).

Kurultay'ın ardından basında yer alan değerlendirmeler genel olarak CHP'nin bir muhasebesi niteliğinde olmuştur. Ahmet Emin Yalman'a göre; Halk Partisi'nde bariz bir liderlik buhranı söz konusudur. Yalman'a göre sarf edilen bütün güzel sözlere rağmen Halk Partisi iktidarı kaybetmeyi bir türlü içine sindiremeyenlerin, meşru yollardan iktidara gelen hükümetleri Türkiye'nin hükümeti diye kabul ederek ona biat etmeyenlere kin güdenlerin, partiyi bu kinin aleti olarak kullananların, feragat diye bir şey tan-mayanlarm elinde esirdir (Yalman, On Birinci Kurultay, 1954). Partiye yakın Halkçı gazetesinde yer alan bir değerlendirmeye göreyse kurultay sonucunda neşredilen beyanname kastedilerek bu beyanname hür dünyaya bir defa daha gösterdi ki memleket bir hukuk nizamının, teminatl demokrasinin harareti içindedir. Rejim buhranı ile karşı karşıyadır. Fakat bütün bunlara rağmen Halk Partisi bir vatanseverler topluluğu olarak bu güçlüklerle mücadele, hatta onlar yenmek azminden hiçbir şey kaybetmemiştir ifadeleri yer almıştır (Birgit, 1954). Partiye yakın bir gazetede bu iyimser yorumlar yer alırken, 
Zafer gazetesinde neşredilen bir köşe yazısında ise açıkça dillendirilmeyen bazı hususlar çıplak bir şekilde ifade edilmiştir. Kurultayın toplanmasındaki tek gayenin parti içindeki bitip tükenmek bilmeyen çekişme olduğu iddiasını taşıyan bir yazıda partideki bazı isimlerin iktidar olamayacaklarını anlayınca birbirlerinin koltuklarına göz diktiklerini savunmuştur. Buna göre; genel idare kurulu ile Genel Sekreter Gülek arasında bir seneden beri şiddetlenen bir ihtilaf olduğu, her iki tarafın da birbirlerine haber vermeden hareket ettikleri ve sonuç itibariyle Gülek'in önünü kesmek isteyenlerin parti meclisi diye bir mekanizma tesis etmeye yöneldikleri vurgulanmıştır. Genel idare kurulu ile Gülek arasındaki bu çekişmeyi muhteris bir grup ile bir tek muhterisin çatışması şeklinde değerlendiren bu yazı İnönü'yü ise bu süreçte en çok yıpranmış isim olarak tavsif etmiştir (Fenik,1954). Ayrıca, kurultay sonunda neşredilen beyannamede yer alan evrensel insan hakları beyannamesi ve hukuk devleti nizamı gibi tabirlerin iç buhranı kamufle etmeye dönük olduğu iddiasının yer aldığı yazıda Kasım Gülek'in partide ihtilaf olmadığı yönündeki demeçlerini yalancllık ve mürailik olarak nitelendirilmiştir. (Fenik M. F., C.H.P.'deki İç Buhran, 1954) Kurultay ile ilgili değerlendirmelerde bulunan Erim'e göre; liderlik vasıflarına haiz olmayan Gülek'in bu kurultayda düşürülmesi uygun olmazdı, çünkü onun demagojik hareketlerinin faydasızlığı iyice anlaşılmış değildi. Yerine geçecek olan kişi onun kadar seyahat edemezdi. Bu da Gülek'in hasretini teşkilata duyuracaktı. Eğer Gülek düşseydi gelecek sefer daha güçlü gelirdi (Erim, 2005, s.555).

Kurultay beyannamesinde yer alan rejim ile ilgili bazı ifadeler iktidar kanadının tepkisini çekmiştir. Bu konuyu Halkçı gazetesindeki köşesinde tartışan Nihat Erim, iktidarın rejim sözcügüüün ağza alınmasına bile hiddet duyduğunu vurgulayarak 1946'dan 1950'ye kadar demokrasi ve hukuk devleti için çırpınır görünenlerin devlet idaresini kendi ellerine geçirdikten sonra istikamet değiştirdiklerini ifade ederek iktidar kanad1nı eleştirmiştir. (Erim, C.H.P. Kurultayı Beyannamesi, 1954) Öte yandan, kurultayda görülen görüş ayrılıklarının eleştirildiği bazı gazetelerdeki haberleri konu eden Cemil Sait Barlas, parti içindeki görüşlerin çeşitli olmasını partinin pek çok kıymetleri içinde topladığının bir delili olarak göstermiştir (Barlas, İktidarın Telâşı Boşunadır, 1954). 


\section{Sonuç}

Türkiye'de siyaset kültürünün şekillenmesinde önemli bir rolü olan Cumhuriyet Halk Partisi birçok bakımdan ilklerin partisidir. Cumhuriyet'in ilanından sonra kurulan ilk parti olması, bizzat Atatürk'ün partinin kurucu başkanı olması ve ittihatçı gelenekten farklı olarak lider kültüne sahip bir yapıda bulunması 27 yıl süren tek parti iktidarı boyunca parti içinde kliklerin ve ayrilıkların yaşanmasının önünde bir engel olmuştur. Ancak çok partili siyasal düzene geçiş siyaset iklimini birçok yönden etkilediği gibi CHP üzerinde de kalıcı etkiler bırakmıştır. Her şeyden önce CHP'li siyasetçiler partiyi yeni döneme adapte etmek için çeşitli yönlerden liberalleşmeye doğru bir eğilim sergilemelerine rağmen partideki eski alışkanlıkların bir çırpıda aşılması mümkün olmamıştır. Parti yönetiminde etki sahibi olanların bir iki değişiklik dışında uzun yıllar boyunca aynı isimlerden seçilmiş olması partide gerçek anlamda radikal denilebilecek değişimler için kolayca karar alınamadığını göstermektedir.

1950 seçimlerinden sonra bir ölçüde tolere edilen CHP üst yönetimi 1954 seçimlerinde alınan onur kırıcı yenilgiden sonra şiddetli eleştirilere hedef olmuşlardır. CHP'de tartışmasız bir sivilleşmenin de amaçlandığı bu yeni dönemde sık sık çıtığ1 yurt gezilerinde partinin il delegeleri tarafından tanınmaya başlayan ve halktan biri görünümü elde eden Kasım Gülek partide ön plana çıkarak İnönü cephesinde yakaladığı zafiyeti de değerlendirip parti genel sekreterliğine seçilebilmeyi başarmıştır. Bu olay $\mathrm{CHP}^{\prime}$ de basit bir görev değişikliğinden öte anlamlar taşımıştır. Her şeyden önce, parti delegeleri nezdindeki imajı günden güne yükselen ve gerek iktidar-muhalefet ilişkileri gerekse de diş politika gibi alanlarda özgün bir politik şahsiyet örneği sergilemesiyle potansiyel bir lider alternatifi olarak görülmeye başlayan Kasım Gülek, CHP içinde belirgin bir meşruiyet krizi ya da parti içi hizipleşmenin öznesi konumunda olmuştur. 1954 seçimlerinden sonra toplanan XI. Kurultay'da da bu özelliği öne çıkan Gülek'in parti içinde muhalefet olma durumu varlığını devam ettirmiştir. Bir bakıma, Gülek'in elde etmiş olduğu genel sekreterlik gücünü sonlandırma amacına matuf olan XI. Kurultay'dan istenen sonucun alınmaması CHP içindeki sorunların kurultaydan sonra da artarak devam etmesine zemin hazırlamıştır. Bir anlamda, CHP'de İnönü etra- 
fında kümelenen grubun parti içi muhalefet odağına karşı sergiledikleri tutumun, daha sonraki yıllarda Türkiye'de siyasal partiler için ortaya atılan liderler oligarşisi tabirinin rüşeym haldeki tezahürü olduğu söylenebilir.

XI. Kurultay'dan sonra toplanan kurultaylarda da Gülek, delegelerden aldığı destekle genel sekreterlik koltuğunu korumayı sürdürmüştür. 1959 'da toplanan XV. Kurultay'da parti meclisine genel sekreteri düşürme yetkisi verildikten sonra eli zayıflayan Gülek, NATO Parlamentolar Grubu'nun düzenleyeceği toplantıda muhalefetten de bir ismin talep edilmesi ve bu iş için Nüvit Yetkin ismi üzerinde karar alınması sonrasında Albay Fens'e yazmış olduğu mektubun ifşa olması üzerine genel sekreterlikten alınmıştır. Gülek'in 1950'den itibaren sürdürmüş olduğu genel sekreterlik makamının parti içinde belirgin bir ikiliğe yol açmasına rağmen İnönü'nün Gülek'i görevden almak için el altından bir çabaya girişmemesi üzerinde durulmayı hak etmektedir. Meşru yoldan genel sekreterlik görevine gelmiş olan Gülek'in gayrı meşru yollarla görevden alınması her şeyden önce kurultayın kararına saygısızlık olacağından parti yönetimi, yıllar boyunca Gülek'in idari görevine katlanmak durumunda kalmıştır. Ancak bu durum, parti içi çekişmelerin, hizipleşmenin ve güç mücadelesinde her yolun mübah görüldüğü bir particilik anlay1şını Türkiye'deki siyasal kültüre miras bırakmıştır. 


\section{EXTENDED ABSTRACT}

\section{Republican People's Party's XITh Congress in The Shadows of Discussions of Election Defeat, Intra-Party Opposition and The Schism (26-30 July 1954) \\ *}

Resul Babaoğlu

Siirt University

Republican People's Party, which plays an important role in shaping the political culture in Turkey, is the first in many ways. Being the first party established after the proclamation of the Republic, the fact that Atatürk himself was the founding chairman of the party and that he had a leader cult unlike the anti-Islamic tradition was an obstacle to the existence of cliques and differences within the party during the 27-year single-party rule. However, the transition to a multi-party political order has a lasting impact on the RPP, as it has affected the political climate in many ways. First of all, although the RPP politicians have tended towards liberalization in various ways in order to adapt the party to the new era, it has not been possible to overcome the old habits of the party in a snap. The fact that those who have influence in party managment has been Chosen from the same names for many Years, except for one or two Changes, shows that it is noy easy to make decisions for the Changes that can be called as radical in the party. At the end of the World War II, with the certainty of Turkey's political and economic interests pointing the West, it is no surprise that there will be a marked liberalization in domestic politics. The collapse of one-party rule in Germany and Italy with the World War II also put the politics in Turkey into an orbit inevitably. In the process until the World War II, despite the negative experiences of Turkey's democracy adventure, a liberal political order was the ultimate goal of bringing the Republican administration in line with democratic principles, as demonstrated by the competitive system undertaken twice during the Atatürk era. As a matter of fact, since the beginning of 1944, the concept of democracy has started to be discussed frequently in the Turkish press. In this process, the change in RPP has become concretely observable. Opposition formations within the party prepared the birth of a new 
party in a short time. The opposition, consisting of Celal Bayar, Adnan Menderes, Refik Koraltan and Fuat Köprülü, laid the foundations of the Democratic Party and brought about the developments that would end the RPP's 27-year single-party power. As can be expected, however, this process did not occur painlessly. As this period, which the Dutch historian Zürcher evaluated under the title of $A$ Restless Democracy, recalled the party fights during the Constitutional Monarchy period, a number of developments which will allow the formation of political culture in Turkey have been seen. Most importantly, the difficulty of adapting to the new role of the RPP, which became an opposition in the elections held on May 14, 1950, and the confusion experienced during the adoption of the new political actors who settled in power with a social formation differentiating from the groups on which the RPP is based, made an impact hampering the relations of power and opposition. The RPP top management, to some extent tolerated after the 1950 elections, has been the target of severe criticism after the humiliating defeat of the 1954 elections. Kasım Gülek, who became known by the provincial delegates of the party and gained the appearance of one of the people in the country trips that he frequently visited in this new period, where an indisputable civilization was aimed in the RPP, succeeded to be elected to the general secretary of the party by evaluating the weakness he caught in the party. This event has more meanings than a simple change of position in the RPP. First of all, Kasım Gülek, whose image of party delegates has been increasing day by day and has been seen as a potential leader alternative in the fields of power-opposition relations and foreign policy as well as being a potential leader alternative, has become a subject within a significant legitimacy crisis within the RPP or internal party faction. In the 11th Congress, which convened after the 1954 elections, Gülek's opposition to the party continued to exist. $\mathrm{n}$ a way, the lack of the desired results from the 11th Congress aimed at ending the general secretary power of Gülek, has given rise to the continuation of the problems within the RPP even after the congress. In a sense, the attitude against the intra-party opposition focus of the group around Inonu in RPP, can be said to be a manifestation in the state of germ for the leaders oligarchy term posed for subsequent years in the political parties in Turkey.

At the congresses that convened after the 11th General Assembly, Gülek continued to maintain the position of general secretary with the support of the delegates. Gülek, who weakened his hand after being given the party 
council of the authority to drop the general secretary in the 15th congress held in 1959, he was taken from the general secretariat upon the letter he wrote to Colonel Fens was disclosed after the request of a member of the opposition at the meeting of NATO Parliaments Group and the decision on the name of Nüvit Yetkin was made. Although the general secretary's office, which Gülek has maintained since 1950, has led to a significant duality within the party, it deserves to be stressed that Inonu did not make an effort to dispose of Gülek. Since the unlawful dismissal of Gülek, who had become the general secretary legitimately, would be disrespectful to the decision of the general assembly, the party management had to endure Gülek's administrative duties for years. But, this situation left a legacy of an understanding partisanship in which rifts within the party, schism and the power struggle seen allowable all over to the political culture in Turkey.

\section{Kaynakça / References}

Ahmad, F. (1996). Demokrasi sürecinde Türkiye (1945-1980). İstanbul: Hil Yayınları.

Akandere, O. (1998). Milli şef dönemi:Çok partili hayata geçişte rol oynayan iç ve dış tesirler 1939-1945. İstanbul: İz Yayıncık.

Arcayürek, C. (1985). Yeni iktidar yeni dönem 1951-1954. Ankara: Bilgi Yayınevi.

Atay, F. R. (1954, Haziran 14). C.H.P. muhalefetinin durumu. Dünya.

Aysal, N. (2012). Atatürk döneminde iç politika. (T. F. Ertan ed.?), Başlangıcindan Günümüze Türkiye Cumhuriyeti Tarihi içinde (s. 161189). Ankara: Siyasal Kitabevi.

Aysal, N. (2017, Mart). Tek parti döneminde Cumhuriyet Halk Partisi Dördüncü Büyük Kurultayı (9-16 Mayıs 1935). History Studies, International Journal of History, 9(9), 21-45.

Babaoğlu, R. (2017). İngiliz belgelerinde Türkiye'de demokrasiye geçiş yılları: 1946 seçimleri ve Demokrat Parti'nin kurulması. Siirt Üniversitei Sosyal Bilimler Enstitüsü Dergisi, 10, 371-402.

Balcı, M. (2015). Sıradışı bir siyasetçi: Kasım Gülek, hayatı ve siyasi faaliyetleri. İstanbul: Yeditepe Yayınları.

Barlas, C. S. (16, Temmuz 1954). C.H.P.'nin durumu V. Son Havadis.

Barlas, C. S. (1954, Temmuz 12). C.H.P.'nin durumu. Son Havadis.

Barlas, C. S. (1954, Temmuz 15). C.H.P.'nin durumu II. Son Havadis. 
Barlas, C. S. (1954, Temmuz 30). İktidarın telâşı boşunadır. Son Havadis.

Barutçu, F. A. (1977). Siyasi anılar 1939-1954. İstanbul: Milliyet Yayınları. Birgit, O. (1954, Temmuz 31). Kurultay kapanırken. Halkçı.

C.H.P. Genel İdare Kurulu (1954). C.H.P. Genel İdare Kurulu'nun 11. Kurultaya Sunduğu Rapor 26-7-1954. Ankara: Güzel İstanbul Matbaası.

C.H.P. Genel İdare Kurulu (1954). C.H.P. Genel İdare Kurulu'nun 11. Кurultaya Sunduğu Rapor 26-7-1954. Ankara.

(1953). C.H.P. Genel Sekreteri Kasım Gülek'in C.H.P. Onuncu Kurultay Konuşmaları . X. Kurultay Kararıyla Basılmıştır.

(1954). C.H.P. XI. Kurultayı Genel Başkan İsmet İnönü'nün Açış Nutku. Ankara: Güzel İstanbul Matbaası.

C.H.P.'de Kulis Arkası Faaliyetler Arttı. (1954, Temmuz 24). Zafer.

CHP Uyanık Olmalı. (1954, Temmuz 18). Yeni Sabah.

Çakmak, F. (2017). Çok partili siyasi hayata geçiş sürecinde CHP Kurultay Görüşmeleri ve müfettiş raporlarına göre parti teşkilatının karşılaştığı sorunlar (1945-1950). Çağdaş Türkiye Tarihi Araşırmaları Dergisi, 17(34), 319-348.

Çavdar, T. (1994). Cumhuriyet Halk Partisi (1950-1980). Cumhuriyet Dönemi Türkiye Ansiklopedisi C.8 içinde (s. 2024-2042). İstanbul: İletişim Yayınları.

Çavdar, T. (1995). Türkiye'nin demokrasi tarihi 1839-1950. Ankara: İmge Kitabevi.

Çevik, İ. (1954, Temmuz 18). C.H.P.'nin atisi ve yeni kararlar. Zafer.

Çevik, İ. (1954, Temmuz 9). C.H.P.'yi islah edecek komisyon faaliyeti. Zafer.

Dodd, C. H. (1991). Ataturk and poltiical parties. M. Heper, and J. Landau içinde, Political Parties and Democracy in Turkey (p. 24-42). London, New york: I.B. Tauris\&Co Ltd.

Erim, N. (1954, Ağustos 2). C.H.P. kurultayı beyannamesi. Halkçı.

Erim, N. (2005). Günlükler 1925-1979. I. Cilt, (Haz. A. Demirel.) İstanbul: Yap1 Kredi Yayınları.

Fenik, A. (1954, Temmuz 30). Kurultaya dair. Zafer.

Fenik, M. F. (1954, Ağustos 2). C.H.P.'deki iç buhran. Zafer.

Fenik, M. F. (1954, Temmuz 23). Islahat istemek bozukluğu kabul etmektir. Zafer.

Fenik, M. F. (1954, Temmuz 19). Şu C.H.P.'deki tesanüt hikayesi. Zafer.

Fenik, M. F. (1954, Temmuz 27). Türk devletine karşı cephe alan kurultay . Zafer. 
(25 Şubat 1954). Genel Başkan İsmet İnönü'nün C.H.P. Kurultayı Olağanstü Toplantısını Açış Nutku.

Giritlioğlu, F. (1965). Türk siyasi tarihinde Cumhuriyet Halk Partisi'nin Mevkii C. I. Ankara: Ayyıldız Matbaası.

Gülen, A. (2018). Türk siyasal hayatında Nihat Erim. Yayınlanmamış Doktora Tezi, İstanbul Üniversitesi, Atatürk İlkeleri ve İnkılap Tarihi Entitüsü, İstanbul.

Güngör, S. (2004). Muhalefette CHP. Ankara: ALternatif Yayınları.

Hanioğlu, M. Ş. (2014, Mart 16). İttihat ve terakki'den günümüze "liderlik", "siyaset" ve "demokrasi". Sabah.

Kahraman, H. B. (2010). Türk siyasetinin yapısal analizi II 1920-1960. İstanbul: Agora Kitaplığı.

Karpat, K. H. (1959). Turkey's politics, the transition to a multi-party system. Princeton, New Jersy: Princeton university Press.

(1956). Kasım Gülek konuşuyor... Günümüzün meşhur politikacıları. İstanbul: Ekicigil Yayınevi.

Kili, S. (1975). 1960-1975 döneminde Cumhuriyet Halk Partisinde gelişmeler, Siyaset bilimi açısından bir inceleme. İstanbul: Boğaziçi Üniversitesi Yayınları.

Koçak, C. (1995). Siyasi tarih (1923-1950). M. T. vd. içinde, Türkiye Tarihi 4, Çağdaş Türkiye 1908-1980, içinde (s. 85-177). İstanbul: Cem Yayınevi.

Koçak, C. (2003). CHP-devlet kaynaşması (1936). Toplumsal Tarih, S. 118, 7479.

Kurultayın İlk Günü. (1954, Temmuz 28). Yeni Sabah.

Nadi, D. (1954, Temmuz 26). Kurultay arifesinde Ankara'dan notlar. Cumhuriyet.

Nart, S. (1984). Türk tarihinde 1945-1960 yılları ve Kasım Gülek. Yayınlanmamış Yüksek Lisans Tezi, . Ankara: Ankara Üniversitesi Sosyal Bilimler Esstitüsü.

Orhon, O. S. (1954, Ağustos 1). Bilanço. Zafer.

Ortaylı, İ. (1983). İmparatorluğun en uzun yüzyıll. İstanbul: Hil Yayınları.

Özbudun, E. (1976). Social change and political partcipation in Turkey. Princeton, New Jersey: Princeton university Press.

Rustow, D. (1969). The development of parties in Turkey. (ed. J. L. Palombara, and M. Weiner) içinde, Politcal Parties and Political Development (s. 107-137). Princeton, New Jersey: Princeton university Press. 
Sayarı, S. (2002). The changing party system. (ed. S. Sayar1 and Y. Esmer), Politics, PartiesEElections in Turkey içinde (s. 9-33). London: Lynne Rienner Publishers.

Toker, M. (1991). Demokrasimizin İsmet Paşalı yılları, DP'nin AltınYılları 19501954. Ankara: Bilgi Yayınevi.

Unat, K. (2016). Durmayalım düşeriz, İktidardn muhalefete CHP'nin Seçim Propagandaları. Ankara: Siyasal Kitabevi.

Uyar, H. (2012). Tek parti dönemi ve Cumhuriyet Halk Partisi. İstanbul: Boyut Yayıncilik.

Uyar, H. (2017). Demokrat Parti iktidarında CHP 1950-1960. İstanbul: Doğan Kitap.

Uzun, H. (2010). Tek parti döneminde yapılan Cumhuriyet Halk Partisi kongreleri temelinde değişmez genel başkanlık, kemalizm ve milli şef kavramları. Çă̆daş Türkiye Tarihi Araştırmaları Dergisi, 9(20-21), 233-271.

Yalçın, H. C. (1954, Temmuz 24). Hayırlı dostlar. Halkçı.

Yalman, A. E. (1954, Temmuz 21). Bozguncu politika. Vatan.

Yalman, A. E. (1954, Temmuz 20). C.H.P.'de iki cephe. Vatan.

Yalman, A. E. (1954, Temmuz 15). C.H.P.'de liderlik. Vatan.

Yalman, A. E. (1954, Ağustos 2). On Birinci kurultay. Vatan.

Yeni Ulus C.H.P.nin resmî yayın organı değildir. (1954, Şubat 14). Yeni Ulus.

Yilmaz, H. (2008). The Kemalist revolution and the foundation of the oneparty regime in Turkey: A political analysis. (ed. S. Y. vd.), içinde, Prof. Dr. Ergun Özbdudun'a Armă̆an (s. 535564). Ankara: Yetkin Yayınevi.

Zürcher, E. J. (2000). Modernleşen Türkiye'nin tarihi. İstanbul: İletişim Yayınevi.

\section{Kaynakça Bilgisi / Citation Information}

Babaoğlu, R. (2019). Seçim yenilgisi, parti içi muhalefet ve hizipleşme tartışmalarının gölgesinde Cumhuriyet Halk Partisi XI. kurultayı (26-30 Temmuz 1954). OPUS-Uluslararası Toplum Araştırmaları Dergisi,13(19), 2679-2708. DOI: 10.26466/opus.591533 